\title{
Assessing the Impacts of Agriculture and Its Trade on Philippine Biodiversity
}

\author{
Andrea Monica D. Ortiz $1,2, *$ (i) and Justine Nicole V. Torres ${ }^{2}$ \\ 1 UCL Institute for Sustainable Resources, The Bartlett School of Environment, Energy, and Resources, \\ Central House, 14 Upper Woburn Place, London WC1H 0NN, UK \\ 2 Parabukas Pte., Inc. Singapore 051531, Singapore; nicole@parabukas.com \\ * Correspondence: m.ortiz@ucl.ac.uk
}

Received: 15 September 2020; Accepted: 21 October 2020; Published: 23 October 2020

check for updates

\begin{abstract}
Many Philippine species are at risk of extinction because of habitat loss and degradation driven by agricultural land use and land-use change. The Philippines is one of the world's primary banana and pineapple producers. The input-intensive style of plantation agriculture for these typically exported crops has many adverse effects on the environment. While global studies have attempted to understand the biodiversity impacts of agricultural goods, there are few studies that have investigated the Philippines specifically. In this study, Philippine policies and data are investigated to better characterize the nexus between agriculture, biodiversity, and trade. An analysis of key national policies highlights that more stringent definitions and protections for biodiversity are needed to recognize the increasing roles that agricultural production, and importantly, its global trade, have on threatened Philippine species. A geographical analysis shows that many banana and pineapple plantations in Mindanao and their surrounding agricultural impact zones overlap with ecologically important areas, such as Protected Areas and Important Bird Areas. Overlaps of recorded species occurrence are observed within the immediate zones surrounding 250 plantations for banana and pineapple in Mindanao, with 83 threatened species of Philippine fauna and tree at risk of exposure to the impacts of intensive agriculture.
\end{abstract}

Keywords: biodiversity; banana; pineapple; agriculture; trade; protected areas; conservation; Philippines

\section{Introduction}

The Philippines is a mega-biodiverse country, with nearly half of its approximately 1100 terrestrial vertebrates and vascular plants endemic to the archipelago [1]. However, decades of poor natural resource management, overexploitation, and human activities have led to critical declines in biodiversity in the Philippines. High rates of deforestation during much of the century have decreased forest cover from about $70 \%$ in 1910 to less than $25 \%$ in 2003 [2,3]. More recent estimates put current Philippine forest cover at $3-5 \%$ of land [1]. Much of the remaining closed canopy (mature) forest can be found on Palawan island, the eastern coast of the island of Luzon, as well as various areas in the southernmost island of Mindanao (Figure 1).

Agricultural land use and land-use change (LULUC, i.e., forest clearing to make land available for cultivation) are some of the main drivers of biodiversity loss [4]. Agricultural land is used to produce commodities for domestic consumption as well as for international trade and export. As of the first quarter of 2020, agricultural exports made up 36.5\% of the Philippines' agricultural trade. Most these were edible fruit and nuts, which collectively amounted to $41.3 \%$ of the total exports and were valued at more than USD 600 million [5]. These agricultural exports typically include high-value products 
such as bananas and pineapples. However, intensively grown crops such as banana and pineapple have significant adverse impacts on various aspects of the environment (e.g., [6-13]).

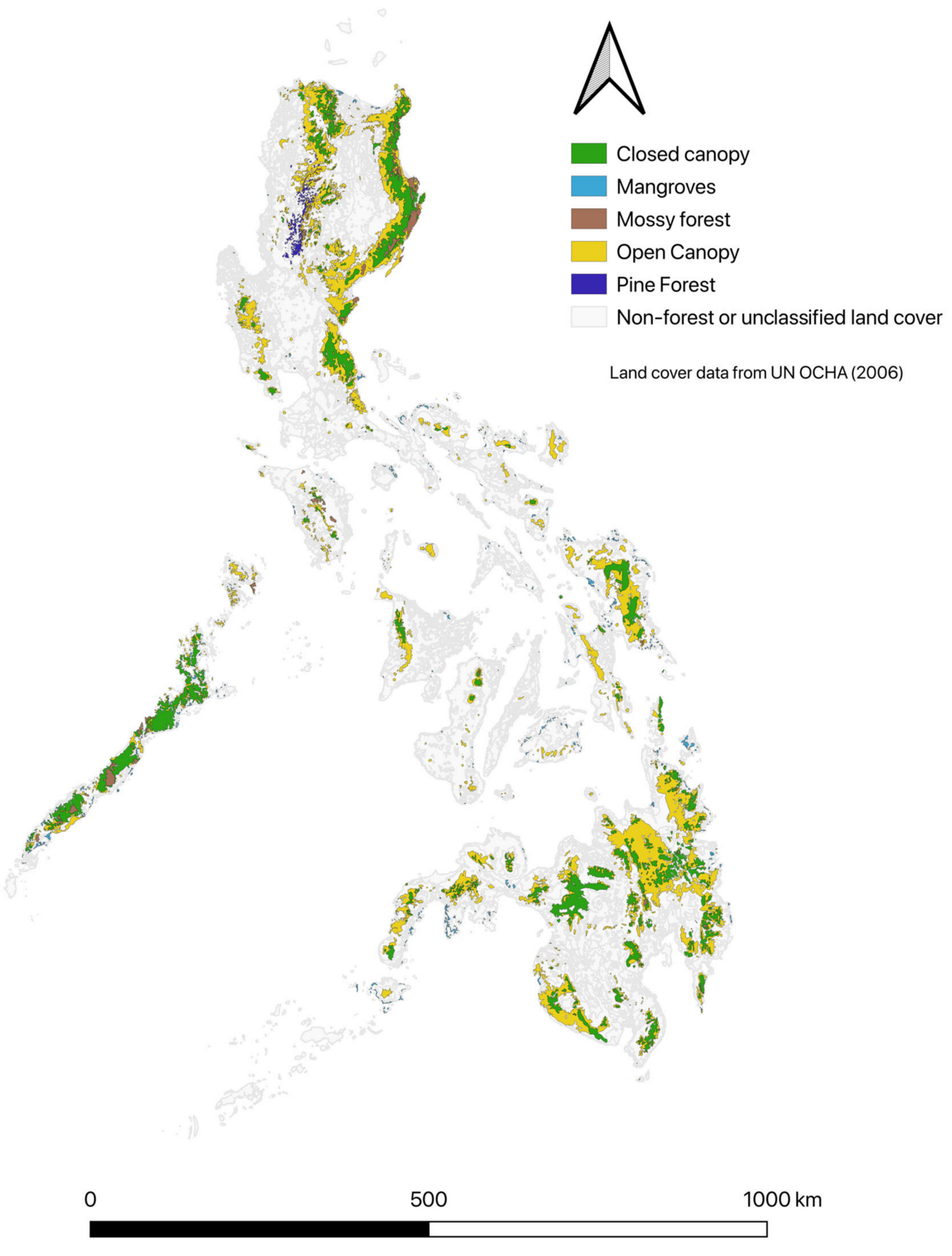

Figure 1. Philippine forest land cover (closed canopy, open canopy, mangrove, mossy, and pine forests), using data and classification from United Nations Office for the Coordination of Humanitarian Affairs (2006) [14].

1.1. Impacts of Intensive Agriculture on the Environment

Agricultural intensification - the process of increasing outputs by increasing inputs-is a major driver of global biodiversity loss [15], and plantation agriculture is its pinnacle. Plantation agriculture 
is thought of as a large-scale, mostly foreign-owned, export-oriented, high-input/high-output farming system [8]. Bananas are usually produced in large plantations with fixed infrastructures and high inputs of fertilizers, pesticides, and irrigation [16]. Both bananas and pineapples are typically cultivated in monocrop (single-crop) plantations, and in the Philippines, mostly in provinces on the island of Mindanao.

Because of their design, plantations increase the concentration of food sources for pests and diseases, which then multiply quickly and can affect the harvest [6]. Plantations already require high levels of input (e.g., fertilizers) for production, but then also need high levels of control inputs (e.g., pesticides) to eliminate competing organisms. These high quantities of inputs can result in chemical leaching, surface runoff, erosion, poor soil fertility, and emissions that have significant negative impacts on the environment through contamination of terrestrial and aquatic ecosystems [6-8].

Pesticide residues from banana and pineapple plantations have been found to lead to fish killings and water quality problems [10]. They have also been documented to cause serious health consequences for both humans and wildlife, particularly birds [6,17]. Runoff and manufacturing processes (e.g., washing of bananas prior to shipping) also provide entry for toxic substances into water [7]. Pests and soil organisms may also gain resistance to pesticides and other chemicals, leading to more use of inputs [6].

These impacts can cascade into further multiple impacts on species and habitats. Plantations contain a low diversity of wildlife compared with natural forests, as they restrict natural habitat and favor only a very restricted number of co-habiting species [8]. They also simplify and homogenize the landscape, which has negative effects on biodiversity by reducing forest cover, increasing the isolation of native species in remnant forest, impeding the movement of species across landscapes, and increasing habitat fragmentation [11]. Furthermore, plantations of pineapple often overlap with buffer zones close to rivers and forests, making agricultural impacts on ecosystems even greater [10].

A significant proportion of the demand for banana and pineapple comes from international trade partners. The Philippines is a major exporter of both crops-the country was the second largest exporter of bananas in 2019 [18] and of pineapple in 2018 [19]. While the international trade of agricultural products can provide significant economic opportunities, as it enables the ability to consume "exotic" or seasonal goods year-round, and benefits from the lower production costs in other countries [20], the impacts on local biodiversity enabled by international food trade agreements can be significant. Additionally, continuous and growing food demand means that the impacts from both agricultural expansion and intensification will continue into the future, bolstered by improved trade connections and an increasing number of regional agreements [21-24].

A significant number of policies in the Philippines are dedicated to protecting and conserving wildlife, habitats and landscapes; however, the consideration of the impacts from agriculture on biodiversity-and importantly, its trade-may not yet be well-considered. Given the importance of biodiversity conservation towards Sustainable Development Goals (e.g., SDG 15, Life on Land), as well as global targets (e.g., the post-2020 conservation targets of the Convention on Biological Diversity) vis-à-vis the increasing demand for food by a growing and more affluent global population, it is crucial to better understand biodiversity losses due to the interactions between agriculture and trade in the Philippines.

\subsection{Research Focus}

While a number of studies have investigated the interlinkages between trade, agriculture, and biodiversity with mention of the Philippines (e.g., [21,25,26]), they focus on the global level. Because of their broad scope, these studies do not account for factors that are important to the Philippine context, including existing policies and regulations, nor are they able to provide spatially explicit information on the risks to species and habitats linked to agricultural production and trade. This limits the usability of global-level studies to inform the transformative changes needed in environmental policy to stop biodiversity loss. It is thus important to identify existing local legal frameworks that 
relate to this important nexus of agriculture, biodiversity, and trade to identify gaps and opportunities in protecting Philippine biodiversity. In addition, a better characterization of species risks related to domestic agricultural production is needed to provide information on biodiversity threats.

In this paper, this need is addressed through a review and analysis of relevant Philippine policies together with an assessment of agriculture, trade, and biodiversity data to identify current risks to species caused by intensive, export-oriented agricultural production of bananas and pineapples. Characterizing these policies and threats may contribute to the state of knowledge on the interactions between trade, agriculture, and biodiversity, as well as provide evidence for strengthening or improving initiatives toward sustainable development amidst biodiversity losses and increased agricultural land use and land-use change.

\section{Materials and Methods}

Philippine policies, as well as agricultural, economic, and biodiversity data on banana and pineapple are investigated in this study (Figure 2). Laws, policies, and bilateral and regional agreements that consider the interactions in the agriculture-biodiversity-trade nexus are reviewed in order to outline potential gaps and opportunities in the protection of biodiversity when agricultural production and trade are considered. These gaps and opportunities are used as basis for recommendations on how the complex feedbacks between agricultural production, species loss and international demand can, and should, be better considered within the Philippine legal context.

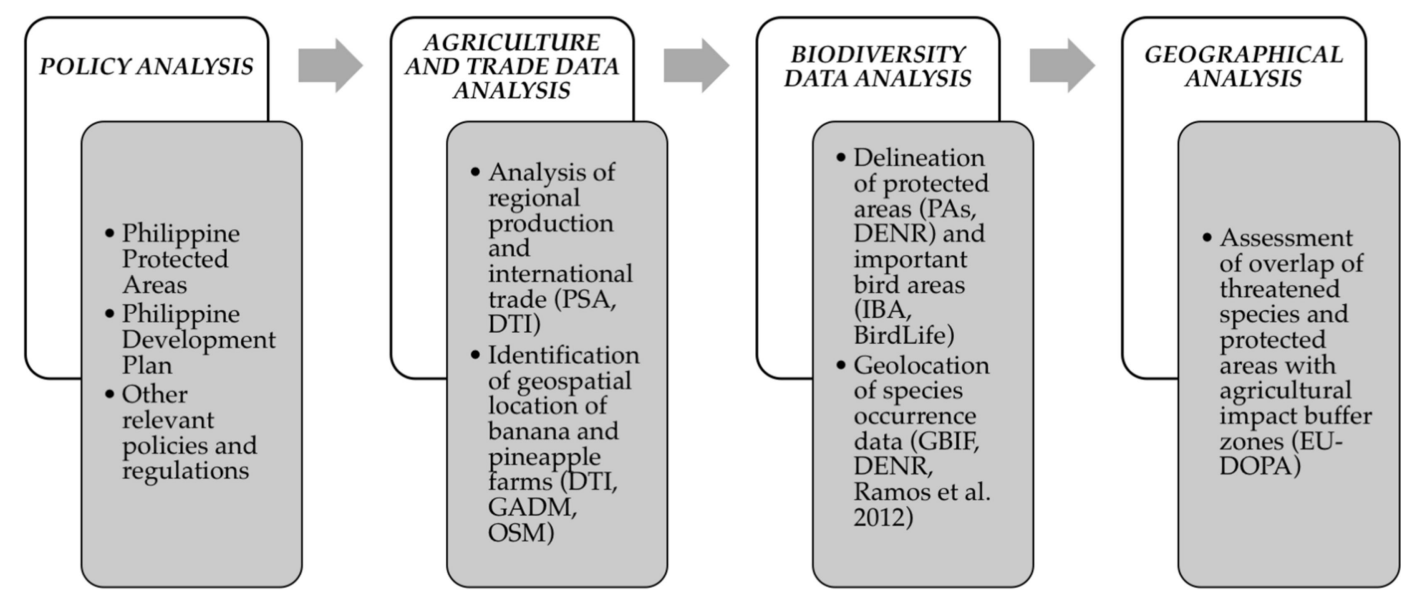

Figure 2. Data and methods used in the study for analyzing Philippine policy, agricultural, trade, and biodiversity data.

To emphasize the impacts on species, agricultural, trade, and biodiversity, data are assessed to investigate the geographic overlap of the area of agricultural impact surrounding banana and pineapple plantations with threatened species' occurrence, and ecologically important areas in Mindanao. Banana and pineapple are chosen for the focus of the study based on their high production, export value, and the large amount of land area dedicated to their cultivation. It is hypothesized that these products, which are highly valued in international markets, are linked to a high number of species under threat.

\subsection{Agricultural Data}

Data on banana and pineapple cultivation was obtained from the Philippine Statistics Authority (PSA) which has records until 2018. Banana varieties were not differentiated in production values, although Cavendish is the primary export variety. Agricultural data on planted area were used to determine which Philippine provinces were the main producers (large-scale, to consider export volume) of the high-value crops. A threshold of more than 10,000 hectares was set to be considered a large provincial producer. 
Additional trade data on production from the Department of Trade and Industry (DTI), PSA and agricultural company profiles were used to determine the foreign country destinations of banana and pineapple exports to link import demand and local production. Site plantation locations for banana and pineapple were obtained from the Bureau of Plant Industry (BPI), the agency responsible for accreditation of prospective growers of fruit and vegetable crops and providing the corresponding documentation for them.

Geographical data used in the study included Philippine country and provincial boundary shapefiles obtained from the Database of Global Administrative Areas (GADM). OpenStreetMap (OSM) was used to obtain approximate latitude-longitude coordinates of these reported plantations at the barangay (village) level. Plantation sites were not included where data was ambiguous (e.g., recorded barangay name did not match geographical records) or when available only at the more coarse-scaled municipality level.

To demonstrate the proximity of known plantations to environmentally important areas, PA shapefiles were obtained from the Philippine GIS Data Clearinghouse and the World Database on PAs. Although agricultural impacts may reach long distances, for instance through runoff entering marine ecosystems, a 10-kilometer agricultural impact zone was added as a buffer around the center of each plantation point to account for varying farm size and leakage/spillover effects from intensive agricultural production. This size of this buffer was also chosen based on the Agricultural Pressure Indicator of the European Commission Digital Observatory for Protected Areas, which can be used to identify protected areas with low or high pressure from agriculture [27]. Different buffer sizes $(2 \mathrm{~km}, 5$ $\mathrm{km}$ ) were also compared to the 10-km buffer to test how this affects the number of threatened species occurrence within proximity of agricultural production.

\subsection{Biodiversity Data}

Species occurrence data were obtained from the Global Biodiversity Information Facility (GBIF) which contains hundreds of millions of records obtained from observations, scientific records, and specimens, to citizen science data collections [28]. Species records from the Philippines were selected to obtain a species occurrence list for land fauna (mammals, birds, reptiles, and amphibians). Species data were cross-referenced to the threatened fauna species list from the Biodiversity Management Bureau of the Philippine Department of Environment and Natural Resources [29] to geo-locate threatened species occurrences. A separate database containing geotagged vulnerable tree species [30] was also included to account for threatened plant biodiversity. Plant and insects are not currently considered but can be pursued in future studies. Marine biodiversity was not considered in the study because of the focus on land-based agricultural impacts.

To identify threatened species within agricultural plantations, firstly, key provinces for large scale banana and pineapple production were identified. PA boundaries, Important Bird Areas [31], plantation sites (with their 10-km buffer), and biodiversity data were overlaid using $\mathrm{R}$ statistical software to analyze interactions between where production is high and intensive, alongside where threatened species are distributed, and where areas have some level of protection. Species which had records of occurrence from GBIF within the buffer zone of plantations were identified. By doing so, these species are recognized as being affected by their proximity and range overlap with intensive agricultural production, a known threat to biodiversity.

\section{Results}

\subsection{Overview of Relevant Philippine Policies}

The Philippines has a number of laws and policies related to the protection of ecologically important areas from adverse human encroachment, including from large-scale agricultural expansion. Of particular importance is the Republic Act 7586, or the National Integrated Protected Areas System (NIPAS) Act of 1992, which governs the establishment and management of Protected Areas (PA) in 
the Philippines. This policy was recently updated by Republic Act 11038, or the Expanded NIPAS (E-NIPAS) Act of 2018. Under these laws, the national PA system encompasses the ecologically rich and unique areas and biologically important public lands that are habitats of rare and threatened species of plants and animals, biogeographic zones, and related ecosystems, whether terrestrial, wetland, or marine ${ }^{1}$. The PA system may be made up of areas classified as National Parks, Natural Biotic Areas, Natural Parks, Natural Monuments, Protected Landscapes and Seascapes, Critical Habitats, and Wildlife Sanctuaries. Each category reflects the area's size, natural conditions, physical features, and purpose.

At the time of its passage, the NIPAS Law was considered a regional leader in the collaborative management of PAs [32], owing to its provision for multi-stakeholder participation through the Protected Area Management Board (PAMB) and Protected Area Management Plan (PAMP). In addition to its mandate to review and approve policies, plans and activities within, and pertinent to the PA, the PAMB is authorized to allocate resources to implement the PAMP, manage the PA incomes and set user fees and charges ${ }^{2}$. It is a multi-stakeholder body, with representation from government, civil society organizations, local communities and the private sector ${ }^{3}$. The PAMP serves as a ten-year framework for the PA's administration, with provisions on zoning, buffer zone management, habitat conservation and rehabilitation, research, and policy development ${ }^{4}$ [33].

At present, the Philippines has recognized 244 PAs. In total, these add up to 7.76 million hectares of terrestrial, wetland, and marine ecosystems. Terrestrial PAs in particular cover $15.6 \%$ of the country's total land area [34], but 64\% of its key biodiversity areas remain unprotected [35]. A 2014 assessment of a sample of PAs identified numerous issues, including "low buy-in" of nearby local governments and communities, conflicts in land tenure, boundaries and zoning, and limitations in PAMB operations [36]. As a result of these, and other challenges, the PAs surveyed were largely unable to address threats to biodiversity and safeguard critical habitats and ecosystems.

To address these issues, the E-NIPAS Act specifies clearer powers and functions for the PAMB and provides for harmonization of the PAMP with other local sectoral plans ${ }^{5}$. Typically, these include the local governments' Comprehensive Land Use Plans and Ancestral Domain Sustainable Development and Protection Plans for PAs that may overlap with Indigenous Peoples' territories. Because of the potential overlaps and interactions between agricultural LULUC and PAs, the NIPAS and E-NIPAS Acts are central to the interactions between agricultural production and biodiversity.

Other instruments and issuances that relate to the interactions between agricultural production, its trade, and the environment include the Philippine Development Plan for 2017 to 2022 (PDP), which identifies agriculture as an important, but poorly performing industry. To address this in the coming years, the government seeks to expand opportunities in the agricultural industry by improving productivity and enhancing commercialization [37]. In particular, the PDP points out the economic potential of high-value crops such as bananas and pineapples to the rapidly expanding export market, noting that production of these markedly increased from 2013 to 2015. Responding to this, interventions were proposed around the goal of diversifying production of selected agricultural commodities in specific regions of the country. Bananas were identified as a potential high-value crop for Northern Mindanao [37].

The PDP lays out strategies for the Environment and Natural Resources sector. However, although these strategies emphasize the need for a ridge to reef approach and sustainable integrated area development, it is unclear how these might factor into the agricultural targets. This is significant,

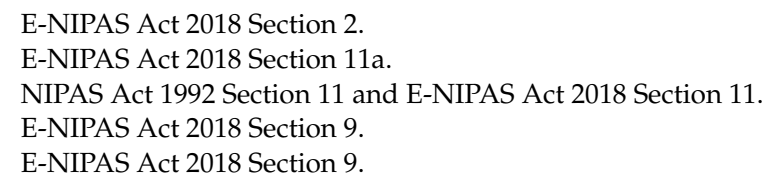


because while crop diversification and intensified commercialization are touted to deliver significant economic benefits, these may simultaneously involve trade-offs in terms of conservation goals.

This is in part because under the Philippine Environmental Impact Statement (EIS) System, agricultural plantations are not automatically considered Environmentally Critical Projects that must comply with the guidelines on Environmental Impact Assessments (EIA) and secure an Environmental Compliance Certificate (ECC) before operations may commence. Nevertheless, plantations may become subject to the EIS system if they fall within the enumerated Environmentally Critical Areas, such as declared national parks, watershed reserves and wildlife sanctuaries, habitats for threatened species of indigenous flora and fauna, and classified prime agricultural lands, among others. In these areas, plantations spanning 1,000 hectares or more must comply with the full EIS process [38].

EIAs and ECCs would be requirements at the outset of a plantation development. For those already in operation, the Philippine Code for Good Agricultural Practice (PhilGAP) for Fruit and Vegetables Farming, which draws from standards adopted by the ASEAN Member States in 2006. Compliant farms and growers are issued corresponding certification. This confirms that they "address environmental, economic and social sustainability which result in safe and quality agricultural products [39]," entitling them to use the official PhilGAP markings for a two-year period. Many large plantations for banana and pineapple crops have been certified under this policy.

\subsection{Regional Production and Trade Analysis}

These policy and regulatory environments have enabled and continue to support the widespread production of banana and pineapple in the Philippines. A significant proportion of these intensive plantations are concentrated in the southern island of Mindanao. For example, data showed that planted area of pineapple plantations in 2018 in two provinces-Bukidnon and South Cotabato-made up over $72 \%$ of all pineapple planted area in the Philippines: 48 thousand hectares (ha) of a total 66 thousand ha were dedicated solely to the crop. For banana plantations, Davao del Norte, Compostela Valley and Bukidnon held the majority of planted area, with more than 20 thousand ha per province. A number of other provinces also had more than 10,000 ha of planted area for banana. Apart from Iloilo, Isabela, and Southern Leyte, all provinces that are large banana producers are in Mindanao (Table 1). Results of the analysis are thus centered around Mindanao because of its high level of agricultural land use and activity, and its role in export-oriented trade due to the large multinational companies with operations there.

Available data were able to provide approximate barangay locations for 227 plantations for banana and 46 for pineapple (226 and 26 at barangay level, respectively). These were associated with 48 companies/groups for banana and 12 for pineapple. Although this may not be a complete figure of the number and scale of plantations in Mindanao-particularly for pineapple which had more limited data compared to banana-data showed a good match between the high-production provinces and the geolocation of these individually identified plantations (See Supplementary information Tables S3 and S4).

Many of the plantations dedicated to pineapple and banana are oriented towards production for export by large multinational companies. Analysis of 2019 trade data and information from individual plantations showed that for bananas, most of the harvest for both bananas and pineapples are exported to Chinese markets, followed by Japan and South Korea (Table 2, Figures 3 and 4). 
Table 1. (a) Large provincial producers: planted area, pineapple (Mindanao); (b). Large provincial producers: planted area, banana (Mindanao).

\begin{tabular}{cc}
\hline Province & $\begin{array}{c}\text { 2018 planted area } \\
\text { (in thousand ha) }\end{array}$ \\
\hline (a) Pineapple \\
\hline Davao del Norte & 25 \\
\hline Compostela Valley & 23.2 \\
\hline Davao del Norte & (b) Banana \\
\hline Compostela Valley & 37.3 \\
\hline Bukidnon & 21.8 \\
\hline Maguindanao & 21.2 \\
\hline Misamis Oriental & 18.2 \\
\hline Davao del Sur & 17.4 \\
\hline Cotabato & 15.4 \\
\hline Agusan del Sur & 14.3 \\
\hline Davao Oriental & 11.2 \\
\hline
\end{tabular}

Table 2. (a) Major export destinations of Philippine pineapple; (b). Major export destinations of Philippine bananas.

\begin{tabular}{|c|c|c|}
\hline & Pineapple & \\
\hline Plantation & Pineapple Variety & Destination \\
\hline \multirow{4}{*}{ Dole } & Tropical Gold & $\begin{array}{c}\text { New Zealand, Malaysia, Philippines, other } \\
\text { Asia Markets }\end{array}$ \\
\hline & Sweetio (with crown) & Japan, Korea \\
\hline & Sweetio (no crown) & China \\
\hline & (b) Banana & \\
\hline Plantation & Banana Variety & Destination \\
\hline \multirow{6}{*}{ Dole } & Regular & China, Korea \\
\hline & Gokusen & Japan \\
\hline & Sweetio & Japan, Korea \\
\hline & Cavendish & Philippines \\
\hline & Super Sweet & China \\
\hline & Señorita & China \\
\hline Del Monte & Cavendish & Japan, Korea \\
\hline TADECO (growing for Del Monte) & Cavendish & $\begin{array}{l}\text { Japan, Hong Kong, China, Korea, Middle } \\
\text { East, Russia, Malaysia and Singapore }\end{array}$ \\
\hline \multirow{4}{*}{ Sumifru } & Kanjukuoh & Japan \\
\hline & Banage & Japan \\
\hline & Gracio & Japan \\
\hline & Unspecified varieties & China, Korea, NZ, Middle East, Russia \\
\hline $\begin{array}{l}\text { TriStar Group (through the } \\
\text { Vizcaya Plantation) }\end{array}$ & Friendly Banana & Japan \\
\hline Unifrutti & Unspecified varieties & China, Japan, Korea, Middle East \\
\hline
\end{tabular}


Philippine banana exports, 2019

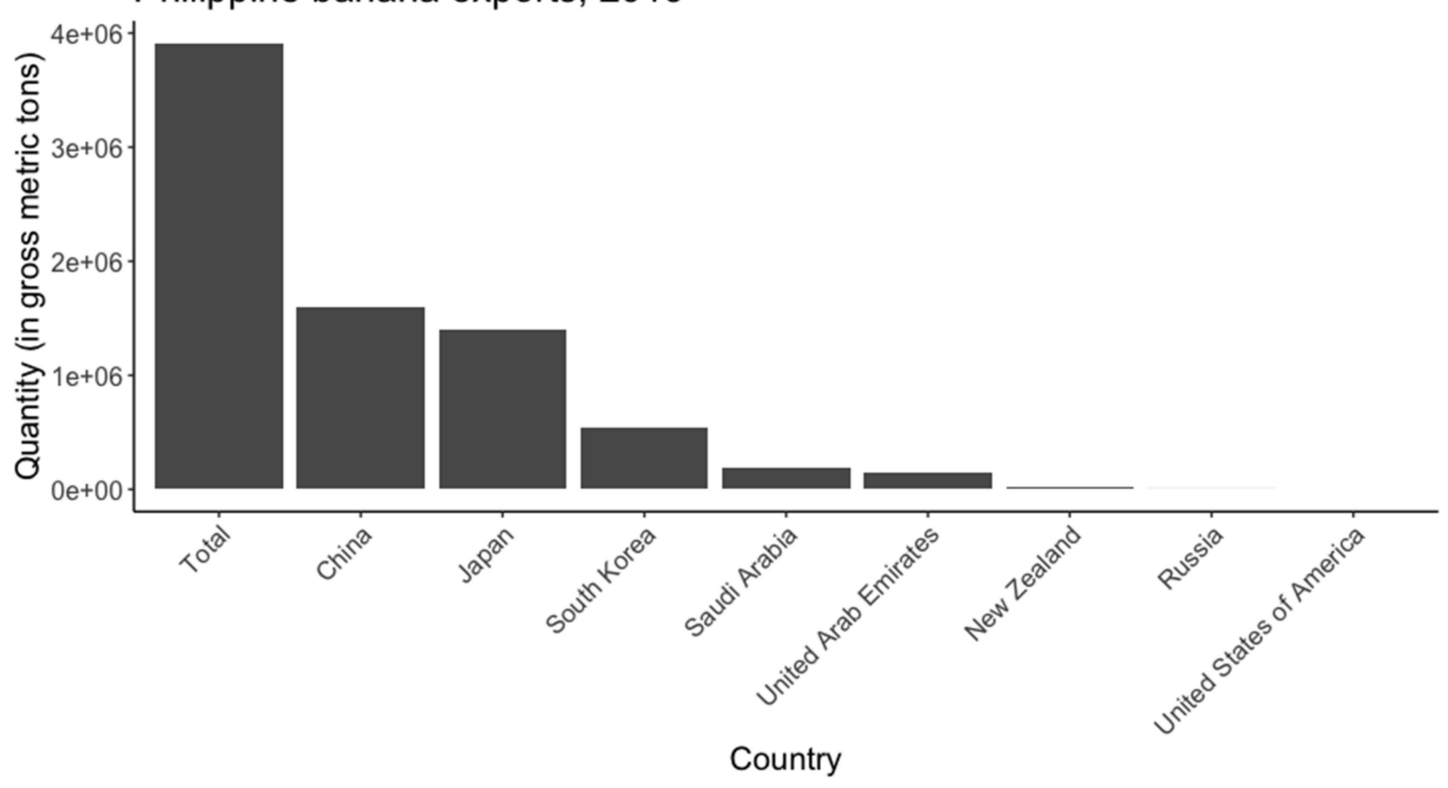

Figure 3. Quantity (in metric tons) of fresh and dried bananas, including plantains traded internationally, by country and with total volume (2019) [40].

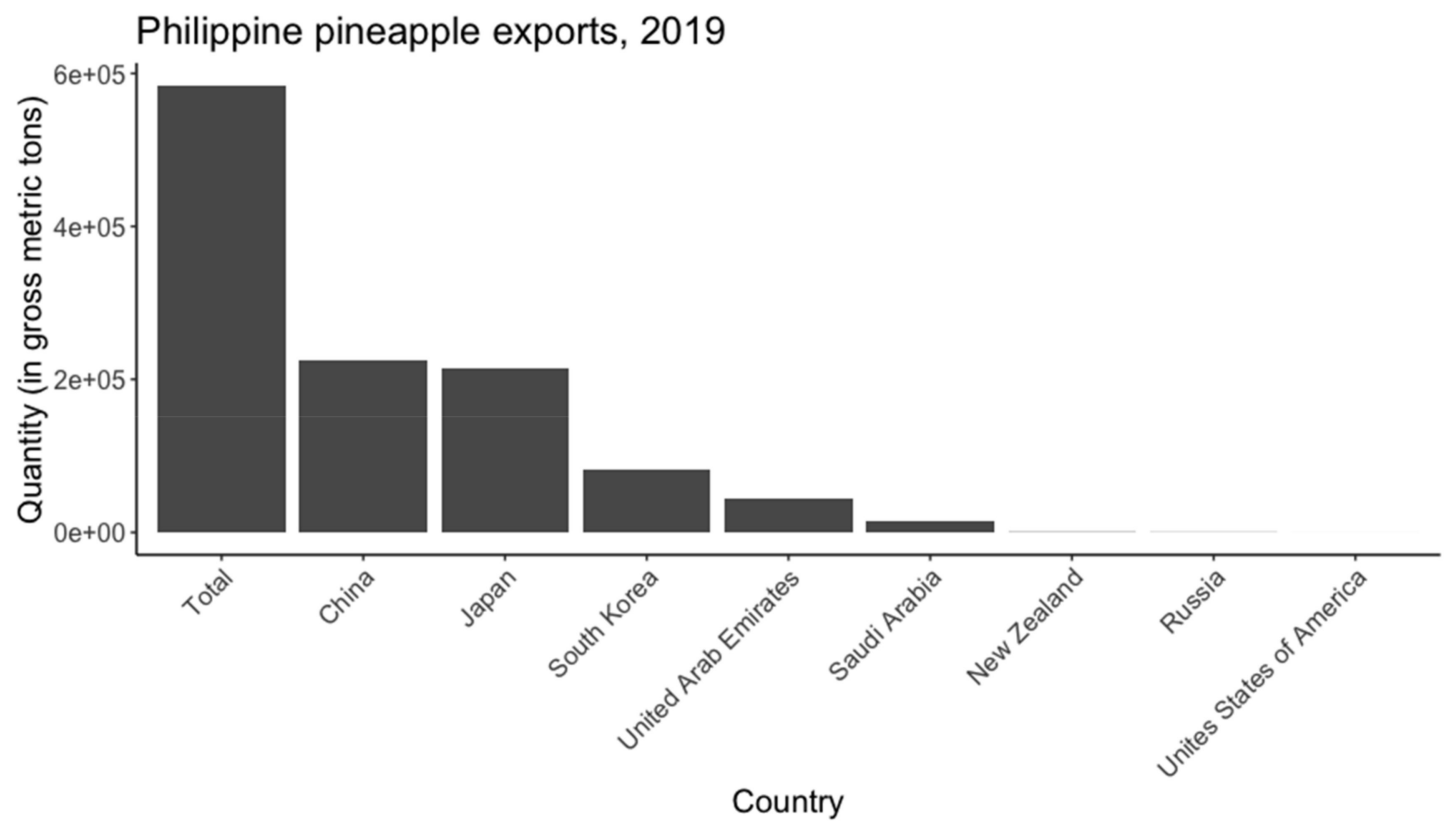

Figure 4. Quantity (in metric tons) of fresh and dried pineapple traded internationally, by country and with total volume (2019) [40].

\subsection{Interactions with Biodiversity}

The geographical analysis showed that many sites in the Philippines are host to high biodiversity, including various threatened species of fauna and trees. Many of the records of species occurrence were found both within and outside of PAs (Figure 5). There were some observable positive biases in species occurrence reporting, for example in the National Capital Region, and sparse data in some regions (e.g., the Cordillera region, where there is an IBA), but these limitations are likely due to the nature of the collection of GBIF records, which is a well-documented limitation of the dataset [41]. 


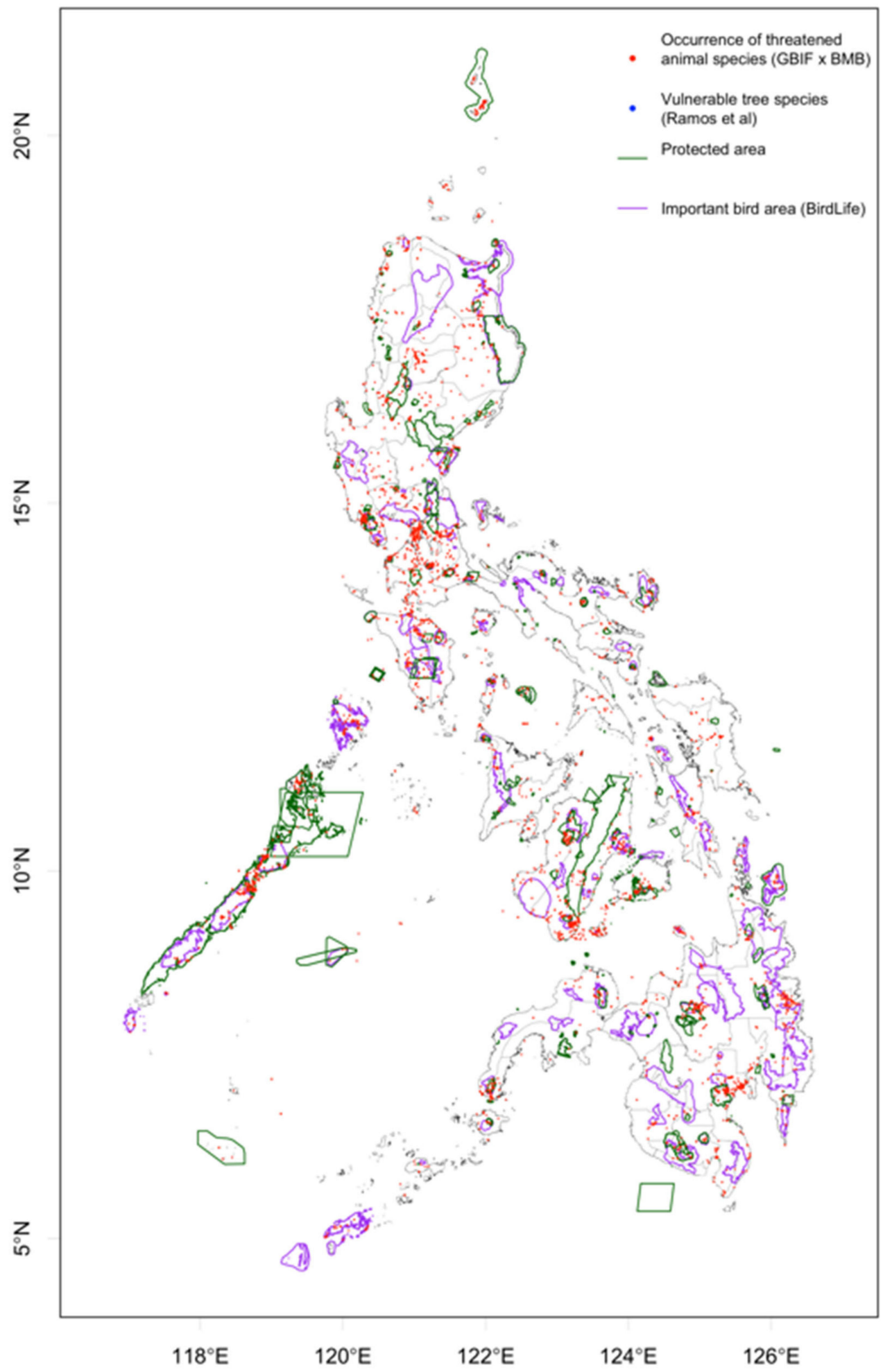

Figure 5. Occurrence of the Department of Environment and Natural Resources - Biodiversity Management Bureau (DENR-BMB) listed threatened fauna from the Global Biodiversity Information Facility (GBIF) database [28,29] and vulnerable tree species from [30]. Protected areas are outlined in dark green and Important Bird Areas [31] in purple.

A map of geolocated banana and pineapple plantations at the approximate barangay level in Mindanao showed that there are many interactions between plantations, PAs, and Important Bird Areas (IBAs). There were a number of both banana and pineapple plantations in Bukidnon that overlap 
with species occurrence records, the Mount Kitanglad and Kalatungan PAs, and several IBAs (Figure 6). There were also a number of overlapping buffer zones between plantations in the provinces of Davao del Norte, Compostela Valley and Davao del Sur, the majority of which are banana plantations. These plantations have direct interactions and potential overlaps between threatened species occurrence with the Aliwagwag Protected Landscape, Mainit Hot Springs Natural Park, and Mount Apo Natural Park (See Appendix A, Table A1, Supplementary Information Tables S3 and S4).

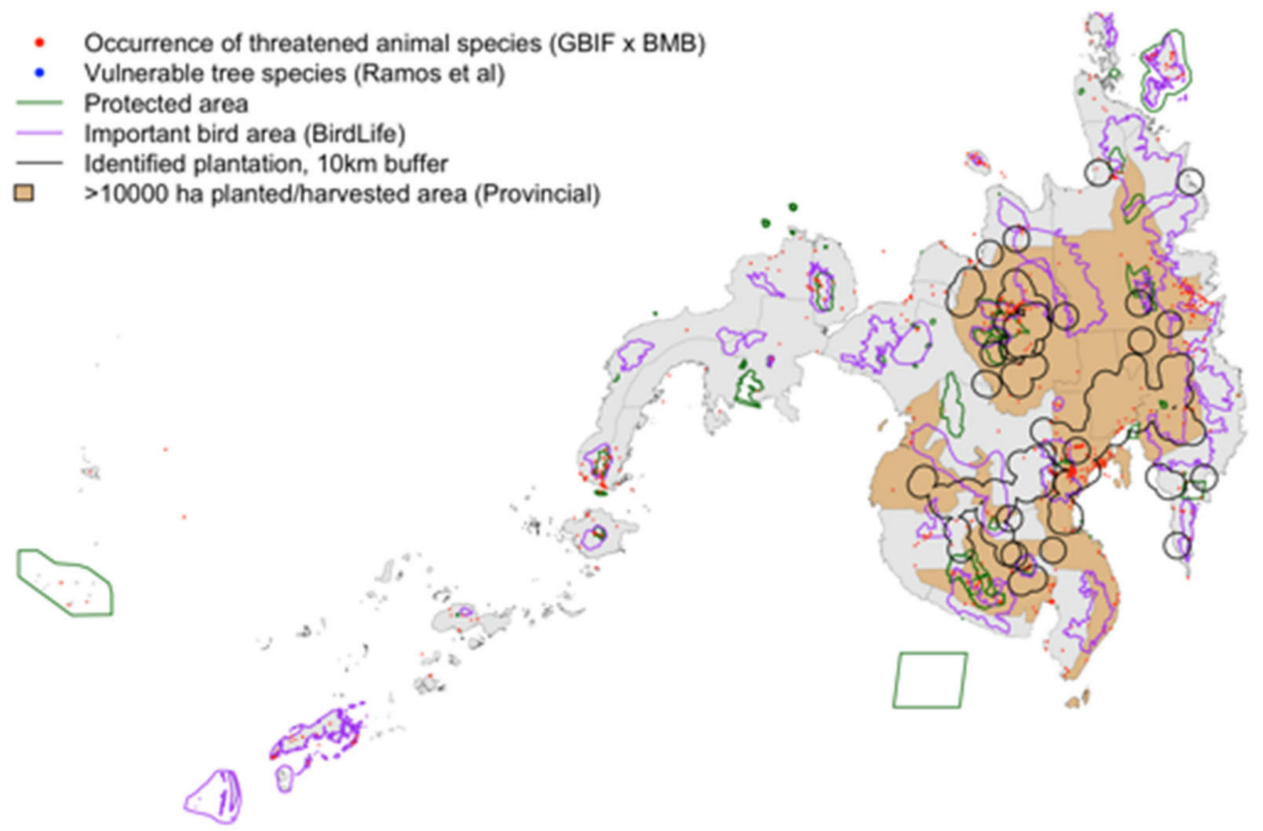

Figure 6. Large provincial producers of high value crops of banana and pineapple in Mindanao. Points indicate threatened species occurrence (tree species and fauna), and circles show identified pineapple and banana plantations with a $10-\mathrm{km}$ buffer.

There were also numerous biodiversity-agricultural land use interactions in Cotabato, South Cotabato, Sultan Kudarat, and Maguindanao with an overlap of the 10-km agricultural buffer zone with the Allah Valley watershed/natural areas. This means that there are acute threats to biodiversity, including birds in IBAs, from the loss of natural habitat from plantation-style (monocrop) agriculture. With more complete plantation data, examples of these interactions between agricultural LULUC and biodiversity are likely to be observed elsewhere in the country where plantations are close to natural habitat and other environmentally important areas.

Based on the 10-km agricultural impact zones surrounding pineapple and banana plantations and species occurrence records (Figure 6), there are 83 direct species threats for fauna (56 species) and vulnerable tree species (27) with the 10-km buffer (Table 3, See Supplementary Tables S1 and S2). Due to the numerous overlaps with IBAs (See Figure 6), it is unsurprising that of the 47 of affected species are birds, which are important indicators of biodiversity [42-44]. Some of these are critically endangered species, including the Philippine eagle and Peregrine falcon. Among mammals, there are records of the critically endangered Philippine naked-backed fruit bat occurring in these agricultural areas. 
Table 3. Average number of threatened species per plantation (both fauna and trees, only fauna, and only trees) with recorded occurrence that overlap with agricultural impact buffer zone: 2,5, and 10km. Total indicates number of unique species across all plantations.

\begin{tabular}{ccccccc}
\hline \multirow{2}{*}{$\begin{array}{c}\text { Agricultural Impact } \\
\text { Buffer Zone }\end{array}$} & \multicolumn{2}{c}{ Both Fauna and Trees } & \multicolumn{2}{c}{ Fauna } & \multicolumn{2}{c}{ Trees } \\
\cline { 2 - 7 } & Average & Total & Average & Total & Average & Total \\
\hline $\mathbf{2} \mathbf{~ k m}$ & 0.12 & 34 & 0.18 & 22 & 0.06 & 12 \\
\hline $\mathbf{5} \mathbf{~ k m}$ & 0.82 & 58 & 1.30 & 40 & 0.33 & 18 \\
\hline $\mathbf{1 0} \mathbf{~ k m}$ & 2.61 & 83 & 4.37 & 56 & 0.86 & 27 \\
\hline
\end{tabular}

A large number of endangered birds are also noted to have occurred within the 10-km agricultural impact buffer zones, particularly from the Accipitridae family, which encompasses large birds including eagles, harriers, hawks, and kites, based on GBIF data. Some endangered species from the Psittacidae (true parrot) family and several endangered owl species also occurred in these agricultural areas and their surrounding buffer zones. A number of threatened tree species from [30] are also found within the agricultural zones of pineapple and banana plantations, including the critically endangered kamagong (Diospyros blancoi), and endangered tree species such as the molave (Vitex parviflora), and homboid (Afzelia rhomboidei) (Supplementary Tables S1 and S2).

By varying the agricultural impact zone buffer size $(2 \mathrm{~km}, 5 \mathrm{~km})$, the average number of affected threatened species per plantation, as well as the number of unique species with recorded occurrence in the area increased with buffer size (Figure 7). This indicates that larger plantations and the immediate areas surrounding them overlap with more species' ranges, as can be expected with the expansion of agricultural land use.

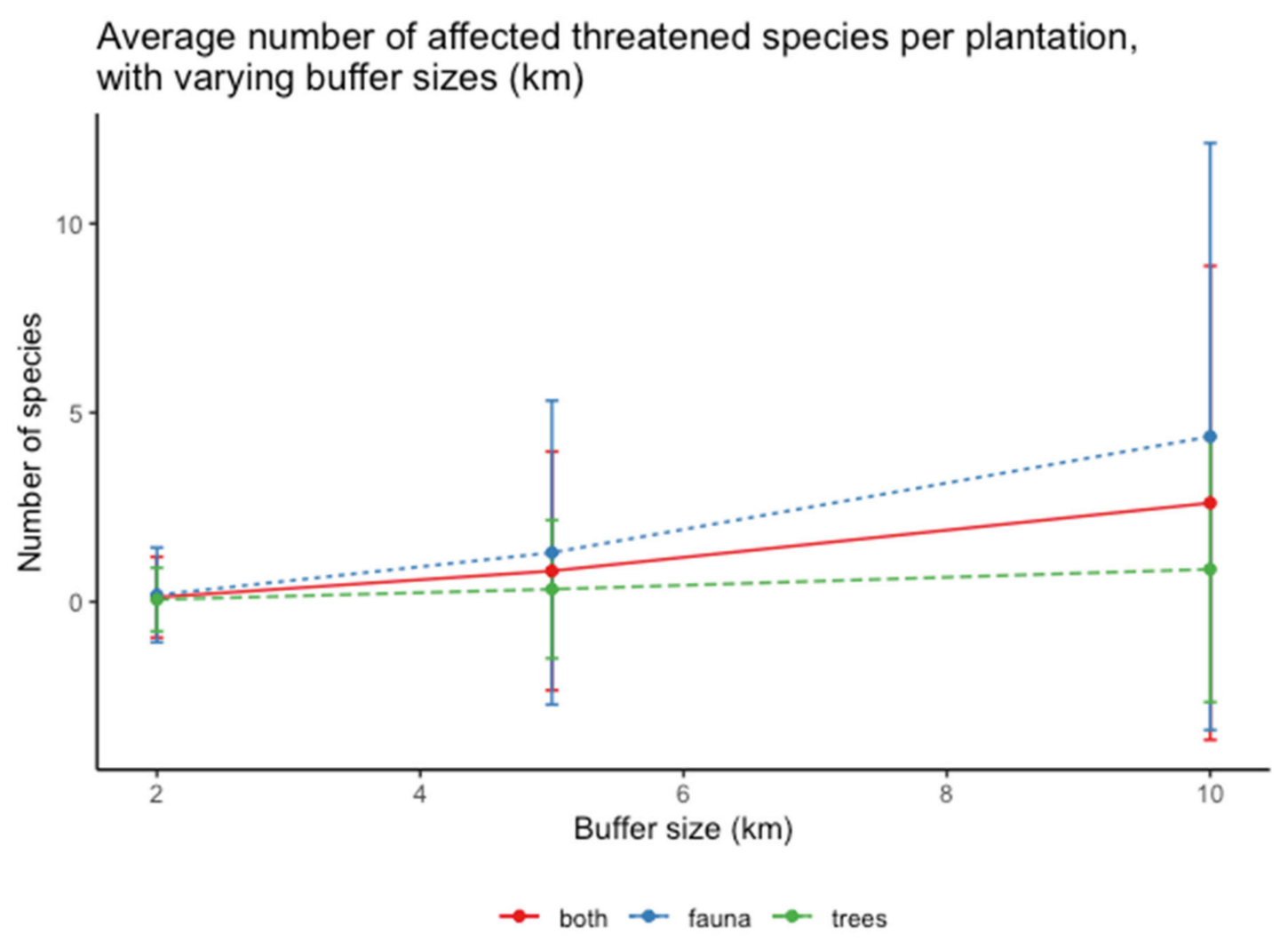

Figure 7. Average number of threatened species per plantation (both fauna and trees, only fauna, and only trees) with recorded occurrence that overlap with agricultural impact buffer zone: 2,5 , and $10 \mathrm{~km}$. Confidence intervals indicate standard deviation. 


\section{Discussion}

In this study, the analysis of biodiversity, agriculture, and trade data showed that the demand for agricultural commodities such as banana and pineapple has significant impacts on Philippine biodiversity. However, the policy analysis shows that these critical links are not always addressed by national-level policies and plans. Rather, much of the growth of the intensive agriculture sector has been made possible by policies and planning documents, which do not often consider the complex, spatially decoupled interactions of supply and demand, and the implications of these interactions on species and habitats. In this section, some of the gaps in policy are discussed to highlight where changes are needed, supported by the results from the geographical analysis.

\subsection{Opportunities and Conflicts with Policy}

Based on the reviewed policies and legislation, there are several points that are worthy of further discussion and investigation. Aims to expand and improve national productivity in agricultural production (e.g., in the PDP and in sector-specific documents such as the Philippine Banana Industry Roadmap), particularly for high-value crops such as banana and pineapple, will likely come into conflict with biodiversity targets, such as those in the National Biodiversity Strategy and Action Plan. Between the economic and agricultural agencies pushing for increases in production area and the environment sector seeking to expand PA coverage, there will simply not be enough space and overlapping land classifications and claims will inevitably need to be resolved [22].

Recommendations to expand or intensify production to meet economic goals or targets need to be mediated by evidence-based discussion of their impacts on dwindling natural habitats and forest cover in the Philippines. Mitigation of the damaging and long-lasting effects of intensive agriculture should also be considered vis-à-vis agricultural expansion/intensification, as well as weighed against national targets on the preservation and protection of remaining habitats and biodiversity. These targets also represent commitments under international law, as they were made pursuant to obligations under the Convention on Biological Diversity and other international agreements.

These discussions are critical and urgent because trade is not expected to slow down. It is projected that global demand for bananas, particularly from the Philippines' major export partners such as China and Japan, will continue to increase in the coming years [18]. The Philippines is likewise finalizing a bilateral trade deal with the United States, which is expected to loosen restrictions on the entry of Philippine pineapples into US markets [45].

This expected inflow of trade could provide opportunities to revisit existing policies and regulations and strengthen their framing of biodiversity and ecosystems-related concerns. At present, these issues are approached generally, and may not always reflect the best available data and scientific analyses. For example, the biodiversity safeguards currently provided for in the PhilGAP Code are very broad. Biodiverse areas are considered "sensitive areas", necessitating additional management measures as regards waste water disposal and/or ground or aerial application of chemicals [39]. The Code, however, does not specify what form these measures should take, or what minimum prescriptions they should comply with.

The Code for Good Agricultural Practice for banana production contains almost no biodiversity safeguards, save for a broad directive on the use of integrated pest management strategies to avoid possible ecological imbalance [46]. Furthermore, it focuses in large part on more internal concerns, such as "microbiological, chemical and physical food safety risks during production, harvesting, and post-harvest handling and distribution".

Interestingly, a listing of issues and concerns identified by industry stakeholders for the Philippine Banana Industry Roadmap for 2019-2022 specifies that banana plantations, particularly for Cavendish and Lakatan varieties are "easy targets for advocacy groups who decry the loss of biodiversity, use of chemicals, and other environmental effects of the production operations" [47]. However, it is not clear how these concerns will be reflected or addressed in policy and its implementation moving forward. Even as the Roadmap proposes strategies to encourage the use of organic fertilizers, improve 
waste water treatment, and promote natural disease control, these are all undertaken with a view to improving productivity, rather than ensuring sustainability in their operations. The national standards for pineapple production, on the other hand, have not been updated since 2004. These do not specify any environmental considerations, dealing exclusively with the most minimum requirements and classifications used to grade the quality of fruit.

One such opportunity to address this nexus between biodiversity and agriculture in this regard is through a draft issuance from the Department of Environment and Natural Resources (DENR) and DA, which provides for the recognition and certification of biodiversity-friendly agricultural practices in terrestrial and aquatic farms. The joint Administrative Order that seeks to mainstream these practices, particularly around PAs, has yet to be approved [34], so it remains to be seen whether this might apply to existing plantations, and if any penalties or disincentives will be applied in case of non-compliance.

Revisiting the Philippine EIS system and its application to large-scale monoculture plantations can ensure that adverse impacts on ecosystems are well-considered prior to any actual operations, and that biodiversity safeguards are met. Policy development is also necessary to address the need to expand the coverage and regulation for PAs. Philippine PAs did not meet the coverage sought under the Aichi targets [35], and without this protection, habitats and species remain at large risk of being lost to human activity, including climate change, and agricultural expansion and intensification. Meeting the 2028 target of a 10\% increase (from the 2015 baseline) in the total area of its terrestrial and wetland PAs would provide needed protection. However, the latest national report submitted to the Convention on Biological Diversity reports insufficient progress in this area [34].

Delineation, monitoring, and law enforcement of additional PAs may be challenging, given limited government resources. Creating new PAs without provisions for adequate support may also exacerbate the acute violence and threats to local forest rangers and protectors, including indigenous peoples, who are often tasked with implementing policies on the ground. On the whole, while legislation and policy may be tools to afford some protection to species and habitats in the Philippines, it is clear that the interactions between human society's needs and nature are very complex. Given this, avenues apart from domestic legislation may need to be explored to craft approaches that balance economic needs with the environmental objectives.

\subsection{Impacts on Threatened Species}

Policy development and reforms are needed to address the biodiversity threats from agricultural production. As shown in the analysis of biodiversity-agricultural land use interactions in Mindanao, although many individually identified plantations may not occur directly within PAs, many plantations' buffer zones overlapped or were in close proximity to recorded locations of many threatened species and to PAs and IBAs. Within buffer zones, some of these impacts (e.g., surface runoff of pesticides, effects of boundaries and habitat fragmentation) may be carried over to harm biodiversity and habitats. Many threatened species are endangered endemic birds, which are known to be sensitive to chemical inputs used in plantations [17] making the presence and proximity of plantations within sensitive and known IBAs a direct threat to biodiversity, particularly to threatened Philippine bird species.

A limitation of the study is that the number of identified plantations, while detailed in spatial scale, may not necessarily be reflective of the true number of banana plantations, including contract growers or smallholder farms (e.g., [48]) which may supply larger banana companies on smaller, fragmented pieces of land. However, these identified plantations and their buffer zones are examples of how different land use types interact with records of species occurrence-a proxy for species presence, absence, and distribution-can already be observed in Mindanao. Although it is not analyzed in this study, systemic monitoring of threatened species over time could reveal whether there are significant correlations, and even a causation, between plantation expansion and declines in species richness and abundance based on their occurrence.

Another consideration is the impact zone chosen for the analysis. Boundaries and buffer zones are important considerations in the context of PAs, as Philippine PAs rely on zoning as a strategy for 
management and administration. This is because zoning systems determine the types of activities that are permissible within the PA. Strict protection zones are closed to human activities by virtue of their significant biodiversity value, or high susceptibility to geo-hazards and other dangers. Multiple use zones, on the other hand, refer to areas wherein settlement, traditional and sustainable land use, including agriculture, agroforestry, extraction, and activities and income generating or livelihood activities may be allowed to the extent prescribed in the PAMP [33].

As shown in Figure 7, increasing the size of the agricultural impact zones (i.e., plantation size) increases the number of species that have overlap with areas of intensive land use. This also indicates that increasing the buffer zones surrounding environmentally important areas-e.g., through ecological corridors or conservation buffer zones-could allow for more species to be under some protective coverage. Indeed, while the analysis here considered varying sizes around the center point of a plantation, the size of very large plantations could easily exceed these safety margins and encroach further into PAs and IBAs. This has already been observed in the Brazilian Cerrado, where the predominance of plantations in the buffer zones of PAs has been found to threaten the effectivity of biodiversity conservation initiatives [49]. Therefore, the size and extent of biodiversity corridors is of extreme relevance for conservation.

Ecological corridors or buffer zones attempt to promote conservation on a larger scale while still allowing some human resource use [50]. They often have ambiguous rules, making their establishment and management a complicated task for both government and non-government agencies [50,51]. However, they provide a number of important functions, such as increasing the amount of available habitat and connectivity between forest fragments, enhancing the conservation of species with high mobility, acting as physical barriers to human encroachment, reducing edge effects, and enhancing environmental services provided by the PA [51-53]. Because of their role in the protection or re-allocation of land away from agricultural or other land use, historically the formal establishment of ecological corridors has not been without contention. However, they warrant attention given the need for landscape-level approaches to conservation [50].

These observations are also seen in the Philippines, where jurisdiction and management over PA buffer zones have historically been difficult [54]. While the NIPAS and E-NIPAS Acts mention ecological, economic, and social criteria, these may be broadly construed and do not specify prescriptions for the assessment and identification of buffer zones. As a result, their extent, measurements and management vary widely among PAs. Moreover, in at least two documented cases, areas with geothermal energy developments were designated as PA buffer zones, although these were well within what would otherwise have been considered the core "strict protection" zones [54].

\subsection{Driving Pressures from Agricultural Trade in Philippine Banana and Pineapple Production}

Many species threats connected to pineapple and banana products are driven by the demand from international trade partners. In 2019, China was the main export partner for both bananas and pineapples, receiving over 1.6 million tons and over 200,000 tons, respectively, followed closely by Japan. It has been observed that China as the primary market for Philippine bananas is a recent development, attributed by analysts to the current administration's efforts at strengthened political and economic ties with Beijing [55].

Aside from this political landscape, export tariffs and sanitary and phytosanitary conditions may account for this shift. Under the Philippines-Japan Economic Partnership Agreement (PJEPA), a bilateral treaty that entered into force in 2008, Philippine bananas are currently levied tariffs of anywhere from $2.5-18 \%$, depending on the season ${ }^{6}$. Japan is also stringent with regard to compliance with sanitary and phytosanitary conditions; for example, in 2018, Japanese authorities required testing for all bananas from the Philippines, after the presence of chemical insecticide Fipronil was found

6 PJEPA Annex I. 
to be in excess of food safety standards [56]. In contrast, under the Tariff Reduction Schedule of the ASEAN-China Free Trade Agreement (ACFTA), Philippine bananas exported to China have been subject to zero tariffs since 2012. Growers have also noted that the Chinese market is less restrictive in terms of sanitary and phytosanitary standards, as well as less particular about the fruits' appearance and packaging [55].

Despite the high tariffs and reduced exports, however, the Japanese market's preference for higher-grade bananas is reflected significantly in the prices that the fruits sell for. Data from the DTI in 2018 shows that although Chinese exports edged out Japan's with a difference in quantity of almost 200,000 tons, this only translated to a little over USD 10 million in terms of value. Early figures from 2019 show a similar trend: between China and Japan, the value difference is less than USD 1 million, although China received almost 130,000 tons more in terms of quantity.

It is likewise interesting how the shift to the Chinese market has had a less conspicuous effect on pineapple exports. While under the ACFTA, pineapple exports from the Philippines also enjoy zero tariffs, trade duties for pineapples under the PJEPA are also considerably less stiff. Instead of a seasonal tariff rate, such as that imposed on bananas, pineapple exports are instead entitled to a tariff rate quota of 1,800 tons, provided that each fruit weighs less than 900 grams.

\subsection{The Increasing Role of International Trade in Biodiversity Impacts}

Reflecting upon these different export partners and the context of the political and economic exchanges between them and the Philippines emphasizes the role of trade in connecting agricultural supply, demand, and biodiversity impacts. The importance of trade in the context of biodiversity and agriculture is becoming more understood through current scientific discourse on increases to the spatial decoupling of food production and demand, bolstered by the ease and ability of trade to make connections between countries (e.g., $[20,25,57,58])$. Although the international trade of products may lead to benefits to the national economy, there are often trade-offs between economy and biodiversity, including increasing environmental pressures [20].

International trade drives biodiversity threats, leaving large environmental and social footprints largely in developing nations that grow certain crops for export [57,59]. A well-known example of this is the China-Brazil soy trade, where lowering of tariffs that made trade easier led to increased deforestation of forests in Brazil to grow soy cheaply for export, a "telecoupling" that has led to significant impacts on biodiversity (e.g., [60-63]) or the EU-Mercosur trade agreement which has had significant impacts on the environment, as well as communities [64]. The number of regional trade agreements has tripled since the year 2000, and nearly all cropland areas brought into production from 1986 to 2009 were used to grow export crops [24].

Therefore, the connection between who is demanding a product and where it is produced is significant-because although the species threats may be local—the driving demand for intensively produced agricultural products is global. Therefore, knowing the enabling policy environment and context such as the Philippine development policies analyzed here, ASEAN tariffs, or Japan's fruit quality standards, is critical. So, while local plantations and agricultural intensification are responsible for the negative impacts that can affect native species, there is an arguably greater need to look at the bigger picture of how biodiversity is affected by global trade. Biodiversity loss should be examined as a global systemic phenomenon, instead of looking at the degrading or polluting producers in isolation [57], particularly because biodiversity impacts are hidden in internationally traded food items [25].

Apart from investigating the connections between land use and consumption (e.g., [65]), it thus becomes important to inform consumers of the embodied impacts of products [25]. A recent approach adopted by consumer-oriented groups dealing with the environmental impacts of palm oil through an eco-labelling effort [66]. However, there should be greater accountability for biodiversity impacts not only on the demand side through advocating for conscientious consumption, but also on the 
producers' side, by demanding for stricter compliance to environmental regulation, and halting further encroachment into dwindling natural habitat for threatened species.

\section{Conclusions}

The Philippines presents a case wherein the domestic policy environment does not adequately address the nexus between large-scale agriculture, Protected Areas and export-oriented trade. Available laws and regulations approach each of these areas as separate and disparate sectors, without sufficient consideration for the interactions and interplay between them.

The analysis shows how the impacts of large-scale agriculture on ecosystems and biodiversity seem to be approached tangentially. These are considered when they are relevant to meeting phytosanitary requirements and quality standards for export crops but are otherwise no greater than the other complaints raised by advocacy groups. While the international trade of high-value commodities such as bananas and pineapples enforces compliance with phytosanitary requirements and quality standards, it stops short of requiring that these crops be produced with minimal adverse impacts on ecosystems and biodiversity. Therefore, this is also where trade might serve to fill the policy gaps that cannot be addressed at the level of domestic legislation-if not directly through provisions in bilateral or regional treaties, then perhaps indirectly, through labelling guidelines that influence consumer preferences and behavior.

Overall, additional and more stringent parameters and safeguards are necessary to better ensure the protection of threatened species, particularly in areas where there are interactions between habitats, PAs, and IBAs. These are urgent as agricultural land is coupled with a political and economic context that emphasizes large-scale and export-oriented trade in high value crops, leading to important opportunities to protect dwindling natural habitats and ecosystems often being overlooked.

The continued increase in agricultural intensification and expansion to grow input-intensive crops such as banana and pineapple has a large impact on biodiversity, particularly for threatened species that are already being affected by habitat loss and the direct impacts of agricultural LULUC. It is strongly recommended that the global, big-picture view of the nexus of agriculture, trade, and biodiversity be considered in national environmental protection laws and programs. Arriving at this holistic perspective will doubtless require that the best available scientific data and analyses inform the design of policies and/or other responses, such as supply-side interventions, regulations in permitting and certification, or by raising consumer awareness to influence market demands.

Supplementary Materials: Supplementary information for this article is available at: https:/tinyurl.com/sibp2020r. Table S1: Threatened animal species within agricultural area and a 10-km buffer zone. CR is critically endangered, EN is endangered, VU is vulnerable, and OTS is other threatened species; Table S2: Threatened tree species within agricultural area and a $10-\mathrm{km}$ buffer zone. CR is critically endangered, EN is endangered, VU is vulnerable, and OTS is other threatened species. n/a indicates no information from the source study.; Table S3. Banana plantations; Table S4: Pineapple plantations.

Author Contributions: A.M.D.O. and J.N.V.T. jointly conceived, performed data analysis, and co-wrote the manuscript. All authors have read and agreed to the published version of the manuscript.

Funding: AMDO is funded by UK Natural Environment Research Council grant (NE/R010811/1).

Acknowledgments: We acknowledge the support of the Parabukas team in the early development of ideas for the manuscript and the feedback from peer reviewers and editors.

Conflicts of Interest: The authors declare no conflict of interest. The funders had no role in the design of the study; in the collection, analyses, or interpretation of data; in the writing of the manuscript, or in the decision to publish the results. 


\section{Appendix A}

Table A1. Potential overlaps of plantations' 10-km agricultural impact zone and Protected Areas.

\begin{tabular}{|c|c|c|}
\hline $\begin{array}{l}\text { Philippine Protected Area, Relevant } \\
\text { Proclamation and Coordinates }\end{array}$ & $\begin{array}{c}\text { Possible Overlaps, by Province } \\
\text { and Municipality }\end{array}$ & $\begin{array}{c}\text { Number of DTI-Registered } \\
\text { Plantations with Potential } \\
\text { Overlaps, by Crop }\end{array}$ \\
\hline $\begin{array}{l}\text { Mt. Balatukan Range Natural Park } \\
\text { Proclamation } 1249 \text { s. } 2007 \text { and E-NIPAS } \\
\text { Coordinates at: } \\
\text { https://www.officialgazette.gov.ph/2007/ } \\
\text { 03/06/proclamation-no-1249-s-2007/ }\end{array}$ & $\begin{array}{l}\text { Misamis Oriental } \\
\text { - } \quad \text { Municipality of Claveria }\end{array}$ & Banana (1) \\
\hline $\begin{array}{c}\text { Mt. Hamiguitan Range Wildlife } \\
\text { Sanctuary } \\
\text { RA } 9303(2004) \\
\text { Coordinates at: } \\
\text { https://www.lawphil.net/statutes/repacts/ } \\
\text { ra2004/ra_9303_2004.html }\end{array}$ & $\begin{array}{l}\text { Davao Oriental } \\
\text { - } \quad \text { Municipality of } \\
\text { - Governor Generoso } \\
\text { Mati City }\end{array}$ & Banana (2) \\
\hline $\begin{array}{l}\text { Mt. Kitanglad Range Protected Area } \\
\text { RA } 8978(2000) \\
\text { Coordinates at: } \\
\text { https://thecorpusjuris.com/legislative/ } \\
\text { republic-acts/ra-no-8978.php }\end{array}$ & 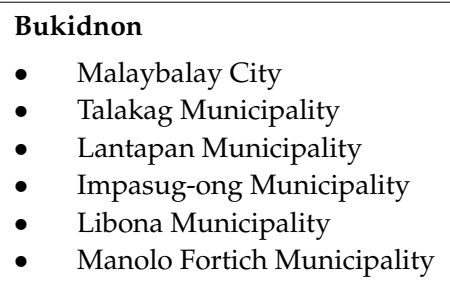 & $\begin{array}{c}\text { Banana (2) } \\
\text { Pineapple (4) }\end{array}$ \\
\hline $\begin{array}{c}\text { Aliwagwag Protected Landscape } \\
\text { Proclamation } 139 \text { s. } 2011 \text { and E-NIPAS } \\
\text { Coordinates at: } \\
\text { https://www.officialgazette.gov.ph/2011/ } \\
\text { 04/05/proclamation-no-139/ }\end{array}$ & $\begin{array}{l}\text { Compostela Valley } \\
\text { - Compostela Municipality }\end{array}$ & Banana (2) \\
\hline $\begin{array}{c}\text { Mt. Apo Natural Park } \\
\text { RA } 9237(2004) \\
\text { Coordinates at: } \\
\text { https://www.officialgazette.gov.ph/2004/ } \\
\text { 02/03/republic-act-no-9237/ }\end{array}$ & $\begin{array}{l}\text { North Cotabato } \\
\text { - } \quad \text { Kidapawan City } \\
\text { - } \quad \text { Makilala Municipality } \\
\text { - } \quad \text { Magpet Municipality } \\
\text { Davao del Sur } \\
\text { - } \quad \text { Digos City } \\
\text { Davao City }\end{array}$ & $\begin{array}{c}\text { Banana (8) } \\
\text { Pineapple (1) }\end{array}$ \\
\hline $\begin{array}{c}\text { Mainit Hot Springs National Park } \\
\text { Proclamation } 320 \text { s. } 2000 \text { and E-NIPAS } \\
\text { Coordinates at: } \\
\text { https://www.officialgazette.gov.ph/2000/ } \\
\text { 05/31/proclamation-no-320-s-2000/ }\end{array}$ & $\begin{array}{l}\text { Compostela Valley } \\
\text { - Nabunturan Municipality }\end{array}$ & Banana (1) \\
\hline $\begin{array}{c}\text { Mati Protected Landscape } \\
\text { Proclamation } 912 \text { s. } 2005 \text { and E-NIPAS } \\
\text { Coordinates at: } \\
\text { https://www.officialgazette.gov.ph/2005/ } \\
\text { 09/06/proclamation-no-912-s-2005/ }\end{array}$ & $\begin{array}{l}\text { Davao Oriental } \\
\text { - } \quad \text { Mati City }\end{array}$ & Banana (1) \\
\hline $\begin{array}{l}\text { Mt. Kalatungan Range Natural Park } \\
\text { Proclamation } 305 \text { s. } 2000 \text { and E-NIPAS } \\
\text { Coordinates at: } \\
\text { https://www.officialgazette.gov.ph/2000/ } \\
\text { 05/05/proclamation-no-305-s-2000/ }\end{array}$ & $\begin{array}{l}\text { Bukidnon } \\
\text { - } \quad \text { Valencia City } \\
\text { - } \quad \text { Talakag Municipality } \\
\text { - } \quad \text { Maramag Municipality } \\
\text { - } \quad \text { Pangantucan Municipality }\end{array}$ & $\begin{array}{c}\text { Banana (3) } \\
\text { Pineapple (4) }\end{array}$ \\
\hline
\end{tabular}

\section{References}

1. Posa, M.R.C.; Diesmos, A.C.; Sodhi, N.S.; Brooks, T.M. Hope for Threatened Tropical Biodiversity: Lessons from the Philippines. Bioscience 2008, 58, 231-240. [CrossRef] 
2. Kastner, T.; Nonhebel, S. Changes in land requirements for food in the Philippines: A historical analysis. Land Use Policy 2010, 27, 853-863. [CrossRef]

3. Kastner, T. Trajectories in human domination of ecosystems: Human appropriation of net primary production in the Philippines during the 20th century. Ecol. Econ. 2009, 69, 260-269. [CrossRef]

4. Chaudhary, A.; Pfister, S.; Hellweg, S. Spatially Explicit Analysis of Biodiversity Loss Due to Global Agriculture, Pasture and Forest Land Use from a Producer and Consumer Perspective. Environ. Sci. Technol. 2016, 50, 3928-3936. [CrossRef] [PubMed]

5. Philippine Statistics Authority. Highlights of the Foreign Trade Statistics for Agricultural Commodities in the Philippines: First Quarter 2020 (Preliminary, as of 17 August 2020). Manila, Philippines. Available online: https://psa.gov.ph/content/highlights-foreign-trade-statistics-agricultural-commodities-philippinesfirst-quarter-2020 (accessed on 6 October 2020).

6. Hernandez, C.E.; Witter, S.G. Evaluating and managing the environmental impact of banana production in Costa Rica: A systems approach. Ambio 1996, 25, 171-178.

7. Henriques, W.; Jeffers, R.D.; Lacher, T.E.; Kendall, R.J. Agrochemical use on banana plantations in Latin America: Perspectives on ecological risk. Environ. Toxicol. Chem. 1997, 16, 91-99. [CrossRef]

8. Hartemink, A.E. Plantation Agriculture in the Tropics. Outlook Agric. 2005, 34, 11-21. [CrossRef]

9. Levillain, J.; Cattan, P.; Colin, F.; Voltz, M.; Cabidoche, Y.-M. Analysis of environmental and farming factors of soil contamination by a persistent organic pollutant, chlordecone, in a banana production area of French West Indies. Agric. Ecosyst. Environ. 2012, 159, 123-132. [CrossRef]

10. Echeverría-Sáenz, S.; Mena, F.; Pinnock, M.; Ruepert, C.; Solano, K.; De La Cruz, E.; Campos, B.; Sánchez-Avila, J.; Lacorte, S.; Barata, C. Environmental hazards of pesticides from pineapple crop production in the Río Jiménez watershed (Caribbean Coast, Costa Rica). Sci. Total. Environ. 2012, 440, 106-114. [CrossRef]

11. Shaver, I.; Chain-Guadarrama, A.; Cleary, K.A.; Sanfiorenzo, A.; Santiago-García, R.J.; Finegan, B.; Hormel, L.; Sibelet, N.; Vierling, L.A.; Bosque-Pérez, N.A.; et al. Coupled social and ecological outcomes of agricultural intensification in Costa Rica and the future of biodiversity conservation in tropical agricultural regions. Glob. Environ. Chang. 2015, 32, 74-86. [CrossRef]

12. Jadin, I.; Meyfroidt, P.; Lambin, E.F. International trade, and land use intensification and spatial reorganization explain Costa Rica's forest transition. Environ. Res. Lett. 2016, 11, 35005. [CrossRef]

13. Chopin, P.; Tirolien, J.; Blazy, J.-M. Ex-ante sustainability assessment of cleaner banana production systems. J. Clean. Prod. 2016, 139, 15-24. [CrossRef]

14. United Nations Office for the Coordination of Humanitarian Affairs, "Philippines - Land Cover,". Available online: https://data.humdata.org/dataset/29a3760f-3170-4555-b5d7-1fbd6cfb5a69/resource/5473b66e-37724762-9312-a4e95fa06cb0/download/landcover_w84.zip (accessed on 10 October 2020).

15. Tscharntke, T.; Klein, A.M.; Kruess, A.; Steffan-Dewenter, I.; Thies, C. Landscape perspectives on agricultural intensification and biodiversity â€" ecosystem service management. Ecol. Lett. 2005, 8, 857-874. [CrossRef]

16. Ploetz, R.; Kema, G.H.; Ma, L.-J. Impact of Diseases on Export and Smallholder Production of Banana. Annu. Rev. Phytopathol. 2015, 53, 269-288. [CrossRef] [PubMed]

17. Billeter, R.; Liira, J.; Bailey, D.; Bugter, R.; Arens, P.; Augenstein, I.; Aviron, S.; Baudry, J.; Bukacek, R.; Burel, F.; et al. Indicators for biodiversity in agricultural landscapes: A pan-European study. J. Appl. Ecol. 2007, 45, 141-150. [CrossRef]

18. United Nations Food and Agriculture Organisation. Banana Market Review: Preliminary Results 2019. Rome, Italy. Available online: http://www.fao.org/economic/est/est-commodities/bananas/en/ (accessed on 8 October 2020).

19. Alterndorf, S. Major tropical fruits market review. Rome, Italy. Available online: http://www.fao.org/ documents/card/en/c/ca5692en/ (accessed on 8 October 2020).

20. Fader, M.; Gerten, D.; Krause, M.; Lucht, W.; Cramer, W. Spatial decoupling of agricultural production and consumption: Quantifying dependences of countries on food imports due to domestic land and water constraints. Environ. Res. Lett. 2013, 8, 014046. [CrossRef]

21. Chaudhary, A.; Mooers, A.Ø. Terrestrial Vertebrate Biodiversity Loss under Future Global Land Use Change Scenarios. Sustainability 2018, 10, 2764. [CrossRef]

22. Kehoe, L.; Romero-Muñoz, A.; Polaina, E.; Estes, L.; Kreft, H.; Kuemmerle, T. Biodiversity at risk under future cropland expansion and intensification. Nat. Ecol. Evol. 2017, 1, 1129-1135. [CrossRef] 
23. Delzeit, R.; Zabel, F.; Meyer, C.; Václavík, T. Addressing future trade-offs between biodiversity and cropland expansion to improve food security. Reg. Environ. Chang. 2016, 17, 1429-1441. [CrossRef]

24. Nyström, M.; Jouffray, J.-B.; Norström, A.V.; Crona, B.; Jørgensen, P.S.; Carpenter, S.R.; Bodin, Ö.; Galaz, V.; Folke, C. Anatomy and resilience of the global production ecosystem. Nat. Cell Biol. 2019, 575, 98-108. [CrossRef] [PubMed]

25. Chaudhary, A.; Kastner, T. Land use biodiversity impacts embodied in international food trade. Glob. Environ. Chang. 2016, 38, 195-204. [CrossRef]

26. Nishijima, S.; Furukawa, T.; Kadoya, T.; Ishihama, F.; Kastner, T.; Matsuda, H.; Kaneko, N. Evaluating the impacts of wood production and trade on bird extinction risks. Ecol. Indic. 2016, 71, 368-376. [CrossRef]

27. European Commission Digital Observatory for Protected Areas. Agricultural pressure. Available online: https://dopa.jrc.ec.europa.eu/sites/default/files/DOPA\%20Factsheet\%20H1\%20Agricultural\%20Pressure_0. pdf?fbclid=IwAR2ArES71ClTialG5naPPrnlWxTFvFI_GHxAXNQrVoPQ3VkFO6i7VevQOmg (accessed on 23 September 2019).

28. Global Biodiversity Information Facility. GBIF Occurrence Download. Available online: https://doi.org/10. 15468/dl.nv63by (accessed on 23 September 2019).

29. Republic of the Philippines Department of Environment and Natural Resources Biodiversity Management Bureau. Species list. Available online: https://www.bmb.gov.ph/mainmenu-resources/species-list (accessed on 23 September 2019).

30. Ramos, L.T.; Torres, A.M.; Pulhin, F.B.; Lasco, R.D. Developing a Georeferenced Database of Selected Threatened Forest Tree Species in the Philippines. Philipp. J. Sci. 2012, 141, 165-177.

31. BirdLife International and Handbook of the Birds of the World. Bird species distribution maps of the world. Version 2018.1. Available online: http://datazone.birdlife.org/species/requestdis (accessed on 23 September 2019).

32. Parr, J. Analysis of the Multi-Level Collaborative Management System in Mt. Kitanglad Natural Park, Mindanao, Philippines. Ecosyst. Dev. J. 2017, 7, 1.

33. Republic of the Philippines Department of Environment and Natural Resources. Administrative Order 2019-05 Implementing Rules and Regulations for Republic Act 11038; Republic of the Philippines Department of Environment and Natural Resources: Manila, Philippines, 2019.

34. Republic of the Philippines Department of Environment and Natural Resources. Sixth National Report to the UN Convention on Biological Diversity; Republic of the Philippines Department of Environment and Natural Resources: Manila, Philippines, 2018.

35. Mallari, N.A.D.; Collar, N.J.; McGowan, P.J.; Marsden, S.J. Philippine protected areas are not meeting the biodiversity coverage and management effectiveness requirements of Aichi Target 11. Ambio 2015, 45, 313-322. [CrossRef]

36. Guiang, E.; Braganza, G. Report on the Management Systems and Capacity Assessment of Protected Areas in the Philippines. Deutsche Gesellschaft für Internationale Zusammenarbeit. Available online: https://snrd-asia.org/download/protected_area_management_enhancement_pame/Report-on-theManagement-Effectiveness-and-Capacity-Assessment-of-PA-in-the-Phil.pdf (accessed on 23 September 2019).

37. Republic of the Philippines-National Economic and Development Authority. Philippine Development Plan 2017-2022; Republic of the Philippines-National Economic and Development Authority: Manila, Philippines, 2017.

38. Republic of the Philippines-Department of Environmental and Natural Resources-Environmental Management Bureau. Revised Procedural Manual for Department Administrative Order 2003-30; Republic of the Philippines-Department of Environmental and Natural Resources: Manila, Philippines, 2007.

39. Republic of the Philippines-Bureau of Plant Industry. Administrative Circular No. 1 series of 2018-Rules and Regulations on the Certification of Philippine Good Agricultural Practices (PhilGAP) for Crops, superseding Administrative Circular no. 10 series of 2013. 2018. Available online: http://bpi.da.gov.ph/bpi/images/MEMORANDUM/MEMO\%20Rules\%20and\%20Regulation\% 20PHILGAP\%20For\%20Crops\%20Circular\%2010\%20Series\%202013/MEMO\%20Rules\%20and\% 20Regulation\%20PHILGAP\%20For\%20Crops.pdf (accessed on 23 October 2020). 
40. Republic of the Philippines-Department of Trade and Industry. Philippine Merchandise Exports to the World by Product with Markets and Product Codes - Banana and Pineapple for 2017, 2018 and 2019. Available online: http://www.tradelinephilippines.dti.gov.ph:8080/exports (accessed on 22 October 2020).

41. Beck, J.; Böller, M.; Erhardt, A.; Schwanghart, W. Spatial bias in the GBIF database and its effect on modeling species' geographic distributions. Ecol. Inform. 2014, 19, 10-15. [CrossRef]

42. Blair, R.B. Birds and Butterflies along an Urban Gradient: Surrogate Taxa for Assessing Biodiversity? Ecol. Appl. 1999, 9, 164. [CrossRef]

43. Pereira, H.M.; Cooper, H.D. Towards the global monitoring of biodiversity change. Trends Ecol. Evol. 2006, 21, 123-129. [CrossRef]

44. Schulze, C.H.; Waltert, M.; Kessler, P.J.A.; Pitopang, R.; Veddeler, D.; Mühlenberg, M.; Gradstein, S.R.; Leuschner, C.; Steffan-Dewenter, I.; Tscharntke, T. Biodiversity Indicator Groups Of Tropical Land-Use Systems: Comparing Plants, Birds, And Insects. Ecol. Appl. 2004, 14, 1321-1333. [CrossRef]

45. Simeon, L. Philippines, US trade on pineapples, blueberries to be finalized. The Philippine Star, 27 January 2020. Available online: https://www.philstar.com/business/2020/01/27/1987971/philippines-us-tradepineapples-blueberries-be-finalized (accessed on 7 October 2020).

46. Republic of the Philippines-Bureau of Plant Industry. Philippine National Standard—Code of Good Agricultural Practice for Banana; Republic of the Philippines_Bureau of Plant Industry: Manila, Philippines, 2013.

47. Republic of the Philippines Department of Agriculture. Philippine Banana Industry Roadmap 2019-2022. Available online: https:/www.da.gov.ph/wp-content/uploads/2019/06/Philippine-BananaIndustry-Roadmap-2019-2022.pdf (accessed on 6 October 2020).

48. De La Cruz, J.; Jansen, K. Panama disease and contract farming in the Philippines: Towards a political ecology of risk. J. Agrar. Chang. 2017, 18, 249-266. [CrossRef]

49. De Moraes, M.C.P.; De Mello, K.; Toppa, R.H. Protected areas and agricultural expansion: Biodiversity conservation versus economic growth in the Southeast of Brazil. J. Environ. Manag. 2017, 188, 73-84. [CrossRef] [PubMed]

50. Weisse, M.J.; Naughton-Treves, L.C. Conservation Beyond Park Boundaries: The Impact of Buffer Zones on Deforestation and Mining Concessions in the Peruvian Amazon. Environ. Manag. 2016, 58, $297-311$. [CrossRef]

51. Atsri, K.H.; Abotsi, K.E.; Kokou, K.; Dendi, D.; Segniagbeto, G.H.; Fa, J.E.; Luiselli, L. Ecological challenges for the buffer zone management of a West African National Park. J. Environ. Plan. Manag. 2019, 63, 689-709. [CrossRef]

52. Paolino, R.M.; Versiani, N.F.; Pasqualotto, N.; Rodrigues, T.F.; Krepschi, V.G.; Chiarello, A.G. Uso da zona de amortecimento de uma unidade de conservação de cerrado por mamíferos. Biota Neotrop. 2016, 16, 1-13.

53. De Oliveira, B.R.; Carvalho-Ribeiro, S.M.; Maia-Barbosa, P.M. Rio Doce State Park buffer zone: Forest fragmentation and land use dynamics. Environ. Dev. Sustain. 2020, 1-12. [CrossRef]

54. La Vina, A.G.M.; Kho, J.L.; Caleda, M. Legal Framework for Protected Areas: Philippines. IUCN Environmental Policy and Law Paper (81). Available online: https://www.iucn.org/downloads/philippines. pdf (accessed on 23 September 2019).

55. Venzon, C. China Uses Banana Diplomacy in Philippines to edge out Japan. Nikkei Asian Review. Available online: https:/asia.nikkei.com/Politics/International-relations/China-uses-banana-diplomacy-inPhilippines-to-edge-out-Japan (accessed on 13 September 2019).

56. Banzon, D. Banana Growers Want PH, Japan Officials to Resolve Protocol Issues. Philippine News Agency. Available online: https://www.pna.gov.ph/articles/1066866 (accessed on 23 September 2019).

57. Lenzen, M.; Moran, D.; Kanemoto, K.; Foran, B.; Lobefaro, L.; Geschke, A. International trade drives biodiversity threats in developing nations. Nat. Cell Biol. 2012, 486, 109-112. [CrossRef] [PubMed]

58. Dalin, C.; Rodríguez-Iturbe, I. Environmental impacts of food trade via resource use and greenhouse gas emissions. Environ. Res. Lett. 2016, 11, 035012. [CrossRef]

59. Wiedmann, T.; Lenzen, M. Environmental and social footprints of international trade. Nat. Geosci. 2018, 11, 314-321. [CrossRef]

60. Sun, J.; Tong, Y.-X.; Liu, J. Telecoupled land-use changes in distant countries. J. Integr. Agric. 2017, 16, 368-376. [CrossRef]

61. Liu, J. Forest Sustainability in China and Implications for a Telecoupled World. SSRN Electron. J. 2013, 1, 230-250. [CrossRef] 
62. Carrasco, L.R.; Chan, J.; McGrath, F.; Nghiem, L. Biodiversity conservation in a telecoupled world. Ecol. Soc. 2017, 22, 24. [CrossRef]

63. Gibbs, H.K.; Rausch, L.; Munger, J.; Schelly, I.; Morton, D.C.; Noojipady, P.; Soares-Filho, B.; Barreto, P.; Micol, L.; Walker, N.F. Brazil's Soy Moratorium. Science 2015, 347, 377-378. [CrossRef]

64. Kehoe, L.; Dos Reis, T.N.; Meyfroidt, P.; Bager, S.; Seppelt, R.; Kuemmerle, T.; Berenguer, E.; Clark, M.; Davis, K.F.; Zu Ermgassen, E.K.; et al. Inclusion, Transparency, and Enforcement: How the EU-Mercosur Trade Agreement Fails the Sustainability Test. One Earth 2020, 3, 268-272. [CrossRef]

65. Yu, Y.; Feng, K.; Hubacek, K. Tele-connecting local consumption to global land use. Glob. Environ. Chang. 2013, 23, 1178-1186. [CrossRef]

66. Ostfeld, R.; Howarth, D.; Reiner, D.; Krasny, P. Peeling back the label-exploring sustainable palm oil ecolabelling and consumption in the United Kingdom. Environ. Res. Lett. 2019, 14, 014001. [CrossRef]

Publisher's Note: MDPI stays neutral with regard to jurisdictional claims in published maps and institutional affiliations.

(C) 2020 by the authors. Licensee MDPI, Basel, Switzerland. This article is an open access article distributed under the terms and conditions of the Creative Commons Attribution (CC BY) license (http://creativecommons.org/licenses/by/4.0/). 